once peace is signed, this journey will not be delayed. Meanwhile, the average zoologist who reads Kammerer's paper may be pardoned if he feels that the hypothesis, of wholesale premeditated fraud is a difficult one to sustain.

It may perhaps be said that no notice should be taken of Kammerer's results until some other investigator repeats them. Such a course is not pursued with regard to any other zoological investigations. When new discoveries are published we thankfully receive them. We keep, perhaps, an open mind until they are repeated, but freely concede that a primafacie case has been made out for them.

To Mendelian critics I would point out that the difficulty of instituting experiments designed to test the inheritability of acquired characters is colossal. Compared with them, the carrying out of experiments in Mendelian inheritance is child's play. With the kind concurrence of Dr. Chalmers Mitchell, I have persuaded Mr. E. Boulenger, Curator of Reptiles, to make preliminary arrangements to have some of Kammerer's experiments repeated in the Zoological Gardens. I found that a minimum of six years would be required before decisive results could be obtained. This new paper of Kammerer's appears to represent the result of seven or eight years' work. 'The proper rejoinder of the Mendelian is not to gibe at the absence of confirmatory evidence from other investigators (and some even of this is available), but to obey the Scriptura! injunction, "Go thou and do likewise."

Imperial College of Science, May 7 .

$$
\text { E. W. MacBride. }
$$

\section{The Conditions attached to Government Grants for Scientific Research.}

MAY I again direct attention to the conditions under which grants are made to individual research workers by the Committee of the Privy Council for Scientific and Industrial Research (London: H.M. Stationery Office, IgI9. Price 6d.)? The matter is of some importance, as not only are those who refuse to: accept these conditions debarred from participating in the grants made from the public purse for scientific research, but other sources which used to be available, and to which such conditions were not attached, are also being cut off. I understand, for example, that the Carnegie Trust for the Universities of Scotland intends very largely in the future to discontinue its grants in aid of research, and to refer applicants to the Government.

By accepting a grant under these conditions, a research worker undertakes not to publish his or her results without the consent of the Committee, and gives up the ownership in the commercial rights of his discoveries, which otherwise, under the Patent law, belong to him. It is the Committee, not the inven tor or discoverer, that is to determine to what extent and in what proportion the Committee and those who have made the discoveries are to secure the ownership of the results by patent, presumably on the ground that the Committee has provided the funds for the research. If that is the ground, ought not the Committee to state precisely what is the share it claims, whether the share is limited to the amount of the monetary contribution, or if it intends to make a profit? I understood the money was given by Parliament to foster research, not to exploit it. As it is, a worker accepting a grant places himself absolutely, as regards the legal right to his own property, in the hands of a Committee, and if, as is bound to occur, differences arise as to what is the share of the discoverer or who is the discoverer, the matter is not No. 2586 , voL. I03] put into the hands of an impartial arbitrator to settle, but is settled by one of the parties in the dispute. In precisely the same way, with existing secret patents, if a dispute arises between a patentee and the Grovernment, it is the Treasury, who pays for the use of the patent, that settles the dispute.

The condition is justified on three grounds. First, on the ground of national interest, especially in the present abnormal circumstances, and that it is not in the national interest that results of commercial value should be made available to other countries to the detriment of our own. As regards actual war conditions, patents containing any information likely to be of use to the enemy have not been published, so this is secured independently of the question of the ownership of the patent. As regards the future, one is justified in asking whether it is the intention of the Committee that the results of researches obtained by the expenditure of national funds should be kept secret, as most scientific men would regard this as short-sighted.

The second ground is that, where results are to be patented, delay in publication is in the interest of the investigator. This is scarcely relevant. It is surely in the highest degree dangerous to delay applying for a provisional patent until the results have been communicated to the Committee and its consent obtained, for any person who, by lawful or unlawful means, gets the information is then in a position to prevent the real discoverer from protecting himself.

The third ground is that it is the object of the Department to secure to the discoverer a fair share in any profits that may accrue from his discovery. Admittedly, the class of inventors and disooverers is in very great need of being protected from the sharp practices that have sprung up under the shadow of the Patent law, and primarily from the Government itself. But why should a small part of them, who receive Government funds, be singled out and protected? If the discoverer prefers to secure for himself the legal ownership of his discoveries, rather than for the Committee, I do not think he should be debarred from participating in this money. The most, I think the Committee has a right to stipulate is that its interest is limited to the amount it has contributed, and that, in the event of a dispute, the matter shall be referred to an impartial arbitrator for settlement.

FREDERICK SODDY.

\section{THE ATLANTIC FLIGHT.}

THE attempt to cross the Atlantic by aeroplane, though as yet unsuccessful, has produced one record-breaking long-distance flight. The American seaplane, $\mathrm{NC}_{4}$, has flown, from Newfoundland to the Azores, a distance of $\mathrm{r}_{3} 80$ miles, thus establishing a record for distance. Trepassey Bay was left on May I6 at I0.05 p.m. G.M.T., and Horta, Island of Fayal, Azores, was reached at 1.23 on the following afternoon, the duration of the flight being 15 hours 18 minutes.

Mr. Harry $\mathrm{G}_{b}$ Hawker and Commander Mackenzie Grieve started from St. Johns, Newfoundland, on May 18 , at 5.45 G.M.T., for a direct flight to the British Isles, but no news has since been heard of them. It is greatly to be regretted that this daring attempt has failed, and we sincerely hope that the two brave aviators, who flew the Sopwith machine, have been rescued by a passing ship. 
It is probable that Mr. Hawker's failure was due to bad weather, and in this respect it seems a pity that so difficult a feat should have become a race between various competitors. Had $\mathrm{Mr}$. Hawker waited until the weather conditions were really favourable, there seems little doubt that ke would have succeeded.

In considering the present situation, it is well to realise the immense progress that has been made in the last ten years. In Igog Blériot first flew across the Channel, and his feat was then regarded in very much the same light as is the Atlantic flight to-day. We must, therefore, not be discouraged by the failure of the first attempt to fly direct from the New World to the Old, and although the Atlantic flight cannot now be considered as a commercial project, it may well be that in ten years' time it will be as simple an undertaking as a commercial flight from Paris to London is at the present day.

It. is worthy of note that the great progress in flying range made since Blériot's Channel flight has been due in great measure to improvements in the engine, and only secondarily to better aerodynamic design. It is highly probable that engine improvement will be the main factor influencing the development of long-distance commercial flying in the future.

The main difficulty of trans-Atlantic flying will always be the weather, but it is to be hoped that an extended research into the meteorological conditions at various altitudes will do much to simplify the problem by enabling aviators to choose the most favourable route and altitude of flight.

Meanwhile, we can but await the attempts of other competitors for the honour of the Atlantic conquest by air, in the certainty that effort will not be relaxed until the flight is accomplished, and in the hope that Mr. Hawker and his navigator have been spared to make another attempt.

Trans-Atlantic Flying and Weather.

It cannot be too well understood that a flight from Newfoundland to the Azores at this time of year is vastly different from a flight to the British Isles. The Azores flight is made within a zone where fair weather prevails. The stages to Lisbon and thence to Plymouth may offer considerable difficulties. For seaplanes, and with lonk-out vessels fairly close to hand, the risk to life is greatly lessened.

So far as the direct flight from St. Johns, Newfoundland, to the British Isles is concerned, it is at present not easy to minimise the risks. Weather undoubtedly is the controlling factor. There are usually exceptionally few days in the year when the North Atlantic is free from cyclonic disturbances, but of all seasons the present time is probably normally the most favourable. The conditions, however, vary so immensely in different years that to choose a period for a transAtlantic flight without reference to the actual existing weather conditions involves immense danger. For a practically safe flight eastwards the prevailing distribution of atmospheric pressure over the Atlantic should be anticyclonic, with direct indication that no cyclonic disturbances exist along the route. In these conditions, which synchronous charts of the Atlantic show to exist occasionally, aircraft would have a steady westerly wind orer the whole course. On the other hand, when cyclonic disturbances are known to exist in the open Atlantic, as they have for several days past, and for a much longer period, stormy and probably adverse winds would have to be negotiated for a considerable distance. The information given in the International section of the Daily Weather Report, issued by the Meteorological Office, which includes wireless reports from the Atlantic, shows what complete data have been available for those taking part in the flight. A moderate south-easterly gale was blowing at the surface well to the westward of the Irish coast at the time of the eastern flight, whilst nothing definite was known as to the direction and velocity of the upper air. Information as to the drift of the air over the open sea in any part of the world is of the crudest form, although even that might be of great value.

THE DEVELOPMENT OF AGRICULTURAL RESEARCH AND EDUCATION LN GREAT BRITAIN.

$I^{T}$ was for long a reproach to this country that so little attention was paid to agricultural research and education. The first step to remedy this state of affairs was taken in I9ro, when Mr. Lloyd George set up the Development Commission and provided it with funds for the promotion of research and of various schemes and methods calculated to assist the agricultural industry. Out of its funds the Commission in Igri made a grant to the Board of Agriculture of $50,000 l$. per annum for the carrying out of the Board's scheme to promote agricultural research and education, and this sum was allocated to various institutions and colleges, thereby allowing much-needed extensions of laboratories and staffs. It is a condition of the grant that a report on the work of the institution should be sent each year to the Board, and these reports as published have been duly reviewed in the columns of NATURE.

There is little doubt that this grant saved the agricultural colleges and research institutions from losing their best men. Up to Igro it was recognised that a good man had little prospect in this country, and must perforce seek for posts overseas, either in some part of the Empire or in the United States. A score of names can be recollected of men who went, not primarily because they wanted to go, but because they saw no alternative. Although a few stayed on, they recognised the risk they ran. Had nothing occurred to justify them, the profession would soon, and deservedly, have acquired a bad reputa-

NO. 2586 , VOL. IO3] 